\title{
UREARUISKUTUSTEN VAIKUTUS OMENAPUUN LEHTIEN TYPPIPITOISUUTEEN
}

\author{
ЈАAKKо SÄKÖ \\ Puutarhantutkimuslaitos, Piikkiö
}

Saapunut 12. 4. 1959

Hamil.ton ym. (5) ryhtyivät v. 1939 Yhdysvalloissa tutkimaan omenapuiden typenottoa lehtien kautta ruiskuttamalla niitä erilaisilla typpiyhdisteillä. Käytetyistä aineista urea osoittautui parhaaksi. Näissä alustavissa tutkimuksissa todettiin, että urearuiskutusten avulla on mahdollista tyydyttää nopeasti omenapuiden typentarvetta. Tämä toteamus on vahvistettu sittemmin lukuisilla tutkimuksilla. Niinpä on osoitettu, että kolmella tai neljällä kasvukauden alkupuolella tehdyllä urearuiskutuksella voidaan omenapuiden lehtien typpi- ja samalla niiden klorofyllipitoisuus saada suuremmaksi kuin siinä tapauksessa, että sama typpimäärä annetaan maahan. Sen sijaan sadonkorjuuaikaan mennessä lehtien typpi- ja klorofyllipitoisuuden on todettu laskeneen kummassakin tapauksessa samalle tasolle (4). FISHER (3) on osoittanut, että urean ruiskuttaminen omenapuiden lehtiin tuottaa typen lisäämisessä suuremman tehon verrattuna saman ureamäärän levittämiseen puiden kasvualustoille. Lehdille ruiskutettuna jää typpilannoitteen teho kuitenkin lyhytaikaiseksi. Blasbergin (1) tutkimuksissa ilmeni, että urearuiskutukset lisäsivät omenasatoa, puun kasvua sekä lehtien kokoa. Urearuiskutuksia saaneiden puiden omenien mallon kiinteyden todettiin kuitenkin heikontuneen verrattuna niihin puihin, joille annettiin typpeä vain kasvualustoille. Tästä ei silti huomattu koituvan mitään haittaa siinä tapauksessa, että omenat markkinoitiin normaaliin markkinoimisaikaan. Ruotsissa suoritetuissa kokeissa urearuiskutuksilla on aikaansaatu useissa lajikkeissa myös omenien koon suurentuminen (6).

Urea imeytyy omenapuiden lehtiin, paitsi ilmarakojen kautta, myös suoraan päällysketon läpi sekä lehden ala- että yläpinnasta (8). CooK ja BoyntoN (2) osoittivat, että ureaa kuitenkin imeytyi lehtiin eniten niiden alapinnasta ilmarakojen kautta. Urean otto oli runsainta silloin kun lehtien alkuperäinen typpipitoisuus oli verrattain korkea sekä lämpötila ja ilmanpaine olivat suhteellisen 
alhaiset. Imeytymistä tapahtui eniten ensimmäisten tuntien aikana ruiskutuksesta, mutta sitä jatkui vielä 48 tunnin ajan. Lehtien ottamasta ureasta oli jäljellä kahdeksan tunnin kuluttua $84 \%$ ja 48 tunnin kuluttua $43 \%$.

Puutarhantutkimuslaitoksella Piikkiössä aloitettiin omenapuiden urearuiskutuskokeet v. 1952, jolloin aluksi selvitettiin eri väkevyisten urealiuosten käyttöä. Kokeissa todettiin paineruiskulla ruiskutettaessa $0.75-1.0 \%$ :n urealiuos väkevyydeltään sopivaksi. Nämä väkevyydet aiheuttavat tosin lehtien reunoissa lieviä vioituksia, joista ei kuitenkaan ole havaittu olevan sanottavaa haittaa. Sen sijaan $2 \%$ liuos aikaansai jo voimakkaita vioituksia. Kun käytettiin $0.5 \%$ urealiuosta, vioituksia ei ilmennyt lainkaan, mutta ruiskutusten teho jäi silloin heikoksi. Sumuruiskua käytettäessä on $2.5-3.0 \%$ :n väkevyys osoittautunut sopivaksi.

\section{Kokeiden järjestely}

Vuosina 1954-55 suoritettiin Puutarhantutkimuslaitoksella urearuiskutuskokeet Melba-, Lobo-, Antonovka- ja Åkerö-omenapuulajikkeille. Kustakin lajikkeesta oli kokeissa kahdeksan 9-10 -vuotiasta puuta. Puut kasvoivat nurmikompostissa hietamaassa. Hedelmätarhaa ei kasteltu. Molempina vuosina suoritettiin puille neljä urearuiskutusta (12/6-20/7 1954 ja 6/7-29/7 1955). Ensimmäinen ruiskutus tehtiin heti sen jälkeen, kun puiden kukinta oli päättynyt. Lisäksi annettiin kumpanakin vuonna aikaisin keväällä puiden kasvualustoille ammoniumsulfaattia $400 \mathrm{~kg}$ hehtaaria kohti.

Vuonna 1954 kerättiin kustakin koepuusta lehtinäytteet kolmeen kertaan, nimittäin sen jälkeen kun puille oli annettu kaksi ja neljä ureakäsittelyä sekä kahdeksan viikon kuluttua viimeisestä käsittelystä. Vuonna 1955 otettiin taas lehtinäytteet ennen ensimmäistä urearuiskutusta, neljännen ruiskutuksen jälkeen ja vielä seitsemän viikon kuluttua siitä. Lehtinäytteistä määritettiin typpipitoisuus

Taulukko 1. Kasvukausien 1954 ja 1955 sademäärät kuukausittain Puutarhantutkimuslaitoksella.

Table 1. The monthly rainfalls at the Department of Horticulture during the growing seasons 1954 and 1955.

\begin{tabular}{|c|c|c|c|c|}
\hline $\begin{array}{c}\text { Kuukausi } \\
\text { Month }\end{array}$ & $\ldots \ldots \ldots \ldots$ & 1954 & 1955 & $\begin{array}{c}\text { Normaali } \\
1886-1935 \\
\text { Normal } \\
\text { mm }\end{array}$ \\
\hline $\begin{array}{l}\text { Toukokuu } \\
\text { May }\end{array}$ & $\ldots \ldots \ldots \ldots \cdots \cdots$ & 12 & 57 & 43 \\
\hline $\begin{array}{l}\text { Kesäkuu } \\
\text { June }\end{array}$ & $\ldots \ldots \cdots \cdots \cdots$ & 37 & 32 & 47 \\
\hline $\begin{array}{l}\text { Heinäkuu } \\
\text { July }\end{array}$ & $\ldots \ldots \cdots \cdots \cdots$ & 108 & 9 & 67 \\
\hline $\begin{array}{l}\text { Elokuu . } \\
\text { August }\end{array}$ & $\ldots \ldots \ldots \ldots \ldots \ldots$ & 130 & 5 & 76 \\
\hline $\begin{array}{l}\text { Syyskuu. } \\
\text { September }\end{array}$ & $\ldots \ldots \ldots \ldots \ldots \ldots$ & 86 & 90 & 69 \\
\hline
\end{tabular}


Kjeldahlin menetelmää käyttäen. Määritykset tehtiin Maatutkimuslaitoksella. Vuonna 1954 tutkittiin lisäksi koepuiden kohdalta otettujen maanäytteiden typpipitoisuus.

\section{Koetulokset ja niiden tarkastelu}

Kasvukausien 1954 ja 1955 sadeolot poikkesivat huomattavasti toisistaan (taulukko 1). Vuoden 1954 touko- ja vielä kesäkuussakin olivat sademäärät normaalia pienempiä, mutta sitä vastoin heinä- ja elokuun sademäärät ylittivät huomattavasti näiden kuukausien normaalisademäärät. Vuonna 1955 sen sijaan toukokuun sademäärä oli normaalia suurempi, mutta taas kesä-, heinä- ja elokuussa satoi tavallista vähemmin. Varsinkin heinä- ja elokuu olivat poikkeuksellisen kuivia niiden sademäärien oltua vain 9 ja $5 \mathrm{~mm}$.

Taulukko 2. Urearuiskutusten vaikutus neljän omenapuulajikkeen lehtien typpipitoisuuteen $1954-55$.

Table 2. The effect of the urea sprays on the nitrogen content of leaves of four apple varieties in $1954-55$.

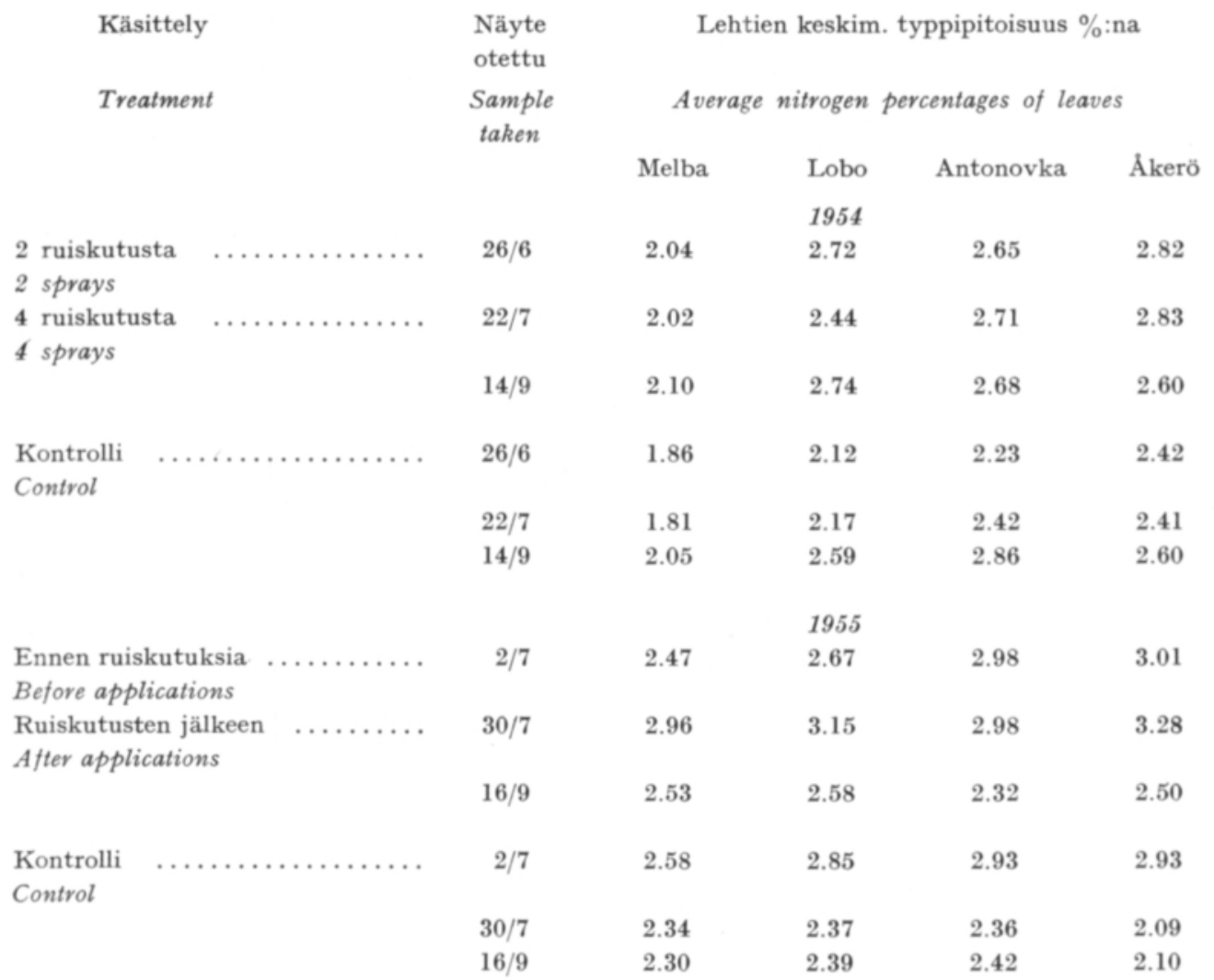

Huom. Prosenttiluvut osoittavat neljästä puusta otettujen näytteiden keskiarvoa. V. 1954 käsittelyt suoritettiin $1.0 \%$ :lla urealiuoksella $12 / 6,23 / 6,7 / 7$ ja 20/7. V. 1955 urea ruiskutettiin $0.75 \%$ :na liuoksena $6 / 7,13 / 7,20 / 7$ ja $29 / 7$.

Note. The figures show the means of samples taken from four trees. In 1954 the applications were given with $1.0 \%$ urea solution at 12/6, 23/6, 7/7 and 20/7. In 1955 the concentration of $0.75 \%$ was used, and the trees were applicated at 6/7,13/7, 20/7 and 29/7. 
1954
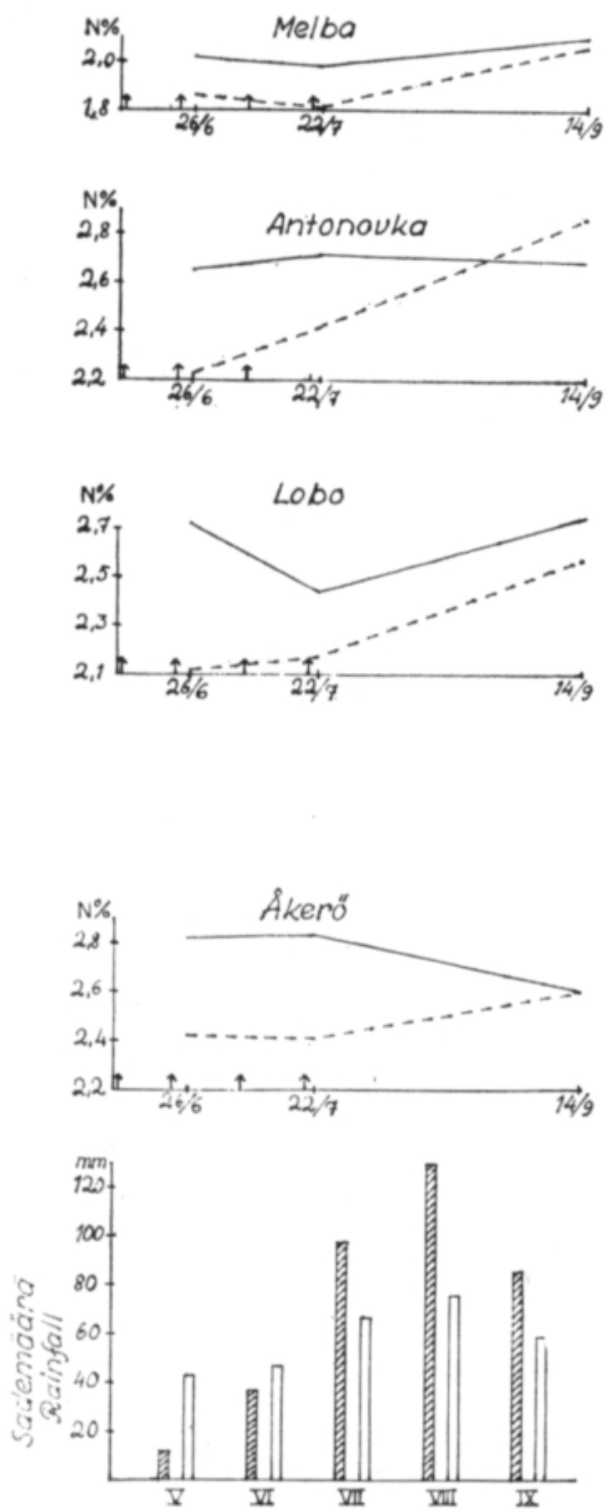

1955
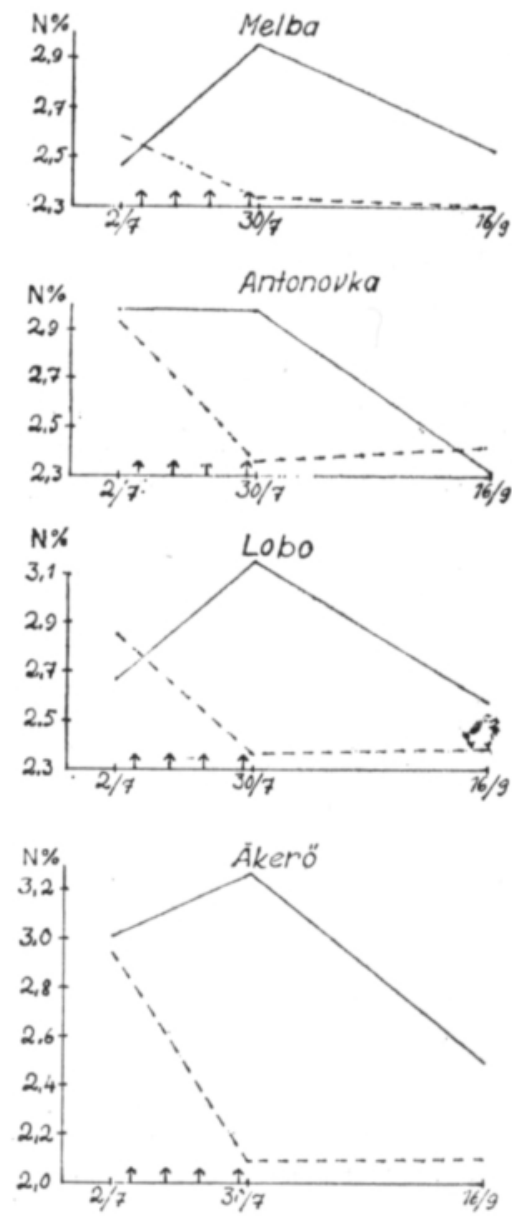
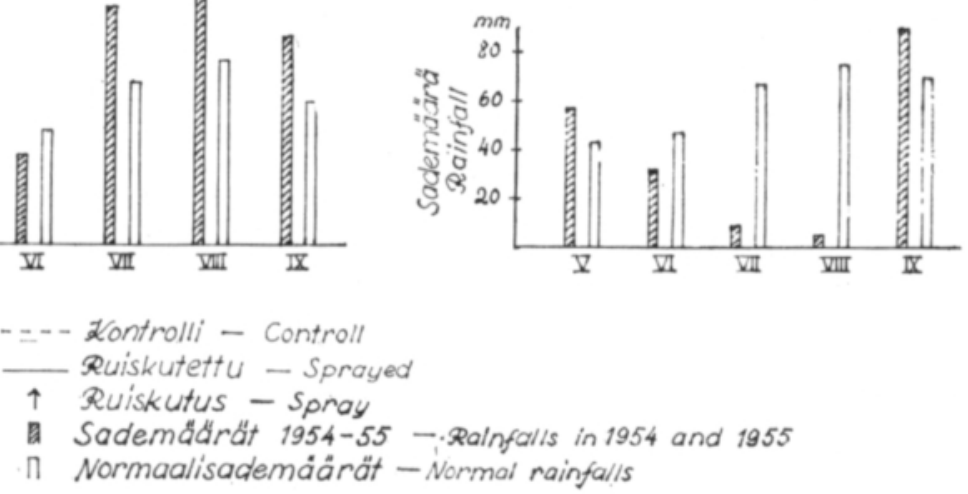

Kuva 1. Neljăn omenapuulajikkeen urearuiskutuksia saaneiden puiden lehtien typpipitoisuus verrattuna kontrollipuiden lehtien typpipitoisuuteen vuosina 1954-55. Lisäksi esitetään kasvukausien sademäärät kuukausittain.

Fig. 1. The nitrogen content of leaves of the four apple varieties treated with urea sprays, compared to the nitrogen level of leaves of the control trees, in 1954 and 1955. In addition the monthly rainfalls of growing seasons are given. 
Tarkasteltaessa kontrollipuiden lehtien typpipitoisuutta voidaan havaita, että siinä tapahtuneet muutokset ovat seuranneet kasvukauden sadeolojen muuttumista. Vuoden 1954 vähäsateisena alkukesänä lehdissä oli suhteellisen vähän typpeä. Runsassateisen loppukesän aikana kontrollipuiden lehtien typpipitoisuus kohosi ja oli syyskuun puolivälissä selvästi suurempi kuin kesä- ja heinäkuussa (taulukko 2, kuva 1). Vuonna 1955, jolloin toukokuun sademäärä oli normaalia suurempi, oli lehdissä typpeä myös suhteellisen runsaasti vielä heinäkuun alussa. Perin kuivan heinäkuun aikana laski typen määrä eri lajikkeiden kontrollipuiden lehdissä kuitenkin $0.3-0.8 \%$. Suurin typpipitoisuuden alentuminen tapahtui tällöin Åkeröpuiden lehdissä. Typen määrä oli lehdissä alhaisena vielä syyskuun puolivälissä. Syyskuun runsaat sateet ilmeisesti paransivat kuitenkin myöhemmin puiden typensaantia.

Tulokset osoittavat, että urearuiskutusten avulla lehtien typpipitoisuus on huomattavasti lisääntynyt kesä-heinäkuun aikana. Sen sijaan syyskuussa, seitsemän-kahdeksan viikon kuluttua viimeisestä urearuiskutuksesta, typen määrä on lehdissä laskenut suunnilleen samalle tasolle kuin kontrollipuissa. Vuoden 1954 kokeessa esiintyi syksyllä jonkin verran epäyhdenmukaisuutta eri lajikkeiden lehtien typpipitoisuuksissa. Tämä johtuu ilmeisesti maan typpipitoisuuden vaihteluista. Samana vuonna tehty maanäytteiden analysointi osoittikin, että Antonovka- ja Åkerö-lajikkeiden kontrollipuiden kohdalla maassa oli typpeä keskimäärin vähän enemmän $(0.004$ ja $0.006 \%)$ kuin urearuiskutuksia saaneiden samojen lajikkeiden puiden kohdalla. Urealiuoksella ruiskutettujen ja ruiskuttamattomien puiden lehtien typpipitoisuuden eroavuudet muodostuivat erityisen selviksi ankaran kuivuuden vaivaamana kasvukautena 1955. Typpeä oli ureaa saaneiden puiden lehdissä ruiskutusten päätyttyä keskimäärin $0.62-1.19 \%$ enemmän kuin käsittelemättömien puiden lehdissä.

Omenapuiden typentarve on huomattavasti suurempi kuin muiden ravinteiden. Niinpä Meurmanin (7) suorittamissa tutkimuksissa, joissa analysoitiin yli 400 lounais-Suomesta kerättyä omenapuiden lehtinäytettä, lehdet sisälsivät typpeä keskimäärin $2.39 \%$, kalia $1.42 \%$ ja fosforia vain $0.17 \%$. Omenapuissa onkin typen puute samoin kuin sen liiallinen esiintyminen jo visuaalisesti melko helposti havaittavissa. Kuten edellä esitetyt koetulokset osoittavat, vaikeutuu puiden typensaanti maasta huomattavasti silloin, kun kasvukauden aikana esiintyy pitkäaikaista kuivuutta eikä kastelua voida järjestää. Tällaisissa tapauksissa urearuiskutusten avulla voidaan nopeasti ja tehokkaasti tyydyttää puiden typentarvetta. Koska urearuiskutuksilla on kuitenkin melko lyhytaikainen vaikutus omenapuun lehtien typpipitoisuuteen, ne eivät ilmeisestikään korvaa kokonaan typenottoa maasta. Sen sijaan lisälannoitteena niillä voidaan katsoa olevan tärkeä merkitys.

\section{Yhteenveto}

Puutarhantutkimuslaitoksella selvitettiin kasvukausina 1954 ja 1955 urearuiskutusten vaikutusta neljän omenapuulajikkeen lehtien typpipitoisuuteen.

Kontrollipuiden lehtien typpipitoisuudessa tapahtuneet muutokset seurasivat 
kasvukauden sadeolojen muuttumista. Sademäärän ollessa pieni laski lehtien typpipitoisuus. Kovan kuivuuden vallitessa aleni lehtien typen määrä $0.3-0.8 \%$ eri lajikkeissa.

Urearuiskutuksilla oli varsin huomattava vaikutus lehtien typpipitoisuuteen. Tämä ilmeni erityisen selvästi poikkeuksellisen kuivana kesänä 1955. Neljännen urearuiskutuksen jälkeen oli käsiteltyjen puiden lehdissä typpeä $0.62-1.19 \%$ enemmän kuin kontrollipuiden lehdissä. Typen määrä oli lehdissä korkeimmillaan ruiskutusten päätyttyä, mutta aleni syksyllä, seitsemän-kahdeksan viikon kuluttua viimeisestä ruiskutuksesta, suunnilleen samalle tasolle kuin kontrollipuissa.

\section{KIRJALLISUUTTA}

(1) Blasberg, C. H. 1953. Response of mature McIntosh apple trees to urea foliar sprays in 1950 and 1951. Proc. Amer. Soc. Hort. Sci 62: 147-153.

(2) Cook, J. A. \& Boynton, D. 1952. Some factors affecting the absorbtion of urea by McIntosh apple leaves. Ibid. 59: 82-90.

(3) Fisher, E. G. 1952. The principles underlying foliage applications of urea for nitrogen fertilization of the McIntosh apple. Ibid. 59: 91-98.

(4) $\rightarrow$ \& СооK, J. A. 1950. Nitrogen fertilization of the McIntosh apple with leaf sprays of urea II. Ibid. 55: 35-40.

(5) Hamilton, J. M. \& Palmiter, D. H. \& Anderson, L. C. 1943. Preliminary tests with uramon in foliage sprays as a means of regulating the nitrogen supply of apple trees. Ibid. 42: $123-126$.

(6) Johansson, E. \& RootsI, N. 1954. Kvävetillföresel till fruktträd genom besprutning med urinämne. Sver. pomol. fören. årsskr. 55: 68-77.

(7) Meurman, O. 1956. Eräitä omenapuiden lehtianalyysien antamia tuloksia. Puutarhavilj. liitt. julk. 115: $1-3$.

(8) Roodney, D. R. 1952. The entrance of nitrogen compounds through the epidermis of apple leaves. Proc. Amer. Soc. Hort. Sci. 59: 99-102.

S U M M A R Y :

THE EFFECT OF UREA SPRAYS ON THE NITROGEN CONTENT OF THE APPLE LEAVES

ЈААКко SÄкӧ

Agricultural Research Centre, Department of Horticulture, Piikkiö

In 1954 and 1955 experiments were made by spraying with 1.0 and $0.75 \%$ urea solution the foliages of the Melba, Lobo, Antonovka and Åkerö apple varieties. In both year eight trees of each variety were included in the trials. All the trees grew in sod mulch in the same block. Urea was applicated four times after the flowering of the trees. In addition to urea sprays the trees received each year early in the spring $400 \mathrm{~kg}$ ammonium sulphate per hectare. The effect of the urea sprays were studied by analysing leaf samples taken three times during the the growing season.

The growing seasons 1954 and 1955 differed remarkably of each others in regard of the monthly rainfalls (Table 1). In 1954 the rainfalls of May and June were small, but in July and August they exceeded markedly those of normals. In 1955 on the contrary the rainfall was in May rather high, but in June, July and August very scanty. Especially July and August were exceptionally dry. 
The results of the experiments are given in Table 2, also in Fig. 1. The nitrogen content of the leaves of the control trees followed the changes which occurred in rainfalls during the growing seasons. When the rainfall got down, the nitrogen of the leaves decreased. This is especially clearly to be seen in the results of 1955 (Fig. 1). The nitrogen content of the leaves of the control trees dropped then during July $0.3-0.8 \%$. Decreasing of nitrogen was greatest in the leaves of the Åkerö trees.

The urea sprays had a very marked effect on the nitrogen content of the leaves. Owing to the sprays it increased considerably. In September, however, seven - eight weeks after the last urea spray, the nitrogen of the leaves reached about the same level as in the control trees. The differences of the nitrogen content of leaves between treated and control trees were very clear in the dry summer 1955. After the fourth application the leaves of treated trees contained $0.62-1.19 \%$ more nitrogen than those of the control trees. 